\title{
Associations between body mass index, body composition and bone density in young adults: findings from a southern Brazilian cohort
}

Isabel Oliveira Bierhals ${ }^{*} \mathbb{D}$, Juliana dos Santos Vaz, Renata Moraes Bielemann, Christian Loret de Mola, Fernando Celso Barros, Helen Gonçalves, Fernando César Wehrmeister and Maria Cecília Formoso Assunção

\begin{abstract}
Background: This study aimed to evaluate the association of body composition components and obesity with bone density.

Methods: Prospective study with data on 2968 members of the 1993 Pelotas Birth Cohort from follow-ups at 18 and 22 years of age. Areal bone mineral density $\left(a B M D, g / \mathrm{cm}^{2}\right)$ was evaluated for whole body, lumbar spine, and femoral neck at 22 years using dual-energy X-ray absorptiometry. Simple and multiple linear regression, stratified by sex, were used to assess the effect of BMI, fat mass (FMI) and lean mass index (LMI), evaluated at 18 and 22 years, and obesity trajectories classified by FMl and categorized as "never", "only at 18 years", "only at 22 years" or "always" on aBMD.

Results: Among men, the largest coefficients were observed for BMl, followed by lean mass and fat mass. Compared to fat mass, lean mass presented the largest coefficients for all sites, with the strongest associations observed for the femoral neck ( $\beta$ : $0.035 \mathrm{~g} / \mathrm{cm}^{2} ; 95 \% \mathrm{Cl}: 0.031 ; 0.039$ for both follow-ups), while the largest effect for FMI was observed for whole-body aBMD at 18 years $\left(\beta: 0.019 \mathrm{~g} / \mathrm{cm}^{2} ; 95 \% \mathrm{Cl}: 0.014 ; 0.024\right)$. Among women, the strongest associations were observed for LMI. The largest coefficients for LMI and FMI were observed for femoral neck at age 18, presented $\beta: 0.030 \mathrm{~g} / \mathrm{cm}^{2}, 95 \% \mathrm{Cl}: 0.026,0.034$ for $L M I$ and $\left.\beta: 0.012 \mathrm{~g} / \mathrm{cm}^{2} ; 95 \% \mathrm{Cl}: 0.009 ; 0.015\right)$ for FMI. Men who were "always obese" according to FMI had smallest aBMD for spine ( $\beta$ : $-0.014 ; 95 \% \mathrm{Cl}$ : -0.029 ; $0.001)$. Women who were obese "only at 18 years" had smallest aBMD for the whole-body ( $\beta$ : $-0.013 ; 95 \% \mathrm{Cl}:-0.023$; $-0.002)$, whereas those who were obese "only at 22 years" had larger whole-body and femoral neck aBMD ( $\beta$ : $0.013 ; 95 \% \mathrm{Cl}$ : 0.009; 0.017 and $\beta$ : 0.027; 95\%Cl: 0.016; 0.038, respectively) and those "always obese" for whole-body aBMD $(\beta: 0.005 ; 95 \% \mathrm{Cl}: 0.001 ; 0.011)$ compared to the reference category.
\end{abstract}

Conclusions: The indexes were positively associated with aBMD in this sample. Fat mass had smaller positive influence on these outcomes than lean mass, suggesting the most important body composition component for bone density is the lean mass.

Keywords: Cohort studies, Bone density, Nutritional status, Body composition, Obesity

* Correspondence: isabelbierhals@gmail.com

Postgraduate Program in Epidemiology, Federal University of Pelotas, Rua

Marechal Deodoro, 1160 - 30 andar, Pelotas/RS 96020-220, Brazil

(c) The Author(s). 2019 Open Access This article is distributed under the terms of the Creative Commons Attribution 4.0 International License (http://creativecommons.org/licenses/by/4.0/), which permits unrestricted use, distribution, and reproduction in any medium, provided you give appropriate credit to the original author(s) and the source, provide a link to the Creative Commons license, and indicate if changes were made. The Creative Commons Public Domain Dedication waiver (http://creativecommons.org/publicdomain/zero/1.0/) applies to the data made available in this article, unless otherwise stated. 


\section{Background}

Peak bone mass is reached at the start of adulthood, determines fracture risk in adults [1], and has the potential to delay the onset of advanced age osteoporosis by 13 years [2]. Factors that affect it negatively, particularly during adolescence, can result in an increased risk of fracture and osteoporosis later in life [3].

The interaction between obesity and bone metabolism is complex and has not been entirely elucidated [4]. By 2030, obesity will affect more than one billion people [57], and total attributed healthcare costs may reach US\$ 957 billion [8]. It had been thought that obesity, when defined as a high body mass index (BMI), had a protective effect on the skeleton [9], since it is related to increased bone mineral content and bone mineral density (BMD) [10-13] and exerts a greater mechanical load on the bones [14]. However, the influence of the two principal components of body weight - fat mass (FM) and lean mass (LM) - on BMD is still a subject of debate [15-18]. While the literature consistently shows that LM has a positive association with bone health $[15,16,19,20]$, the National Osteoporosis Foundation recently concluded that the effect of FM on the accumulation of bone mass in young populations is still open for debate [19].

A wide selection of investigations has observed that adiposity has a negative effect on bone mass [11, 20-24]. In a recent meta-analysis, Dolan et al. [24] stratified samples by age and found that adiposity had a negative effect on the bone mass of people under the age of 25 years, suggesting that the negative influence of increasing adiposity is more striking when bone metabolism is in a state of flux, as is the case during the growth period [24].

The objective of this study was to evaluate the effect of body composition components (FM and LM, evaluated as an index) and BMI at 18 and 22 years and trajectory of obesity among the follow-ups on bone density at 22 years, using data from a population cohort of young adults born in the Southern Brazil and followed since birth.

\section{Methods}

\section{The 1993 Pelotas birth cohort}

In 1993, all maternity units in the city of Pelotas were visited daily, and 5265 births to women residing in the urban area of Pelotas between January 1 and December 31 were identified [25]. A total of 5249 mothers agreed to enroll in the study, and their newborn infants were examined. After the perinatal interviews, subsets were assessed at the ages of 1,3 , and 6 months and at 1, 4, 6 and 9 years. At the ages of $11,15,18$, and 22 years, all members of the original cohort were invited to further assessments. More detailed information on the methodology employed at follow-up assessments is available elsewhere [25-27].

This study uses data from the follow-ups conducted at 18 and 22 years of age on all cohort members for whom information on body composition and BMI was available from both follow-ups and bone mass from the 22-year follow-up. For the latest follow-up, a digital questionnaire was constructed on the REDCap (Research Electronic Data Capture) [28] platform to enable electronic data collection and subsequent construction of a database.

\section{Body composition}

Body composition variables (FM, LM, and bone mass) were measured using dual-energy X-ray absorptiometry (DXA) (Lunar Prodigy Advance - GE ${ }^{\circ}$ ). These examinations were not conducted with pregnant participants or participants in whom there was a suspicion of pregnancy, wheelchair users, people with bone and joint deformities, or those with weight exceeding $120 \mathrm{~kg}$ or height exceeding $192 \mathrm{~cm}$, in accordance with the manufacturer's instructions. To standardize examinations, participants were given appropriate clothing to wear and did not wear anything made of metal.

Both FM and LM at 18 and 22 years of age were expressed in kilos $(\mathrm{kg})$, using whole body scans, and the respective indices were calculated from the ratio of each variable with the square of weight $(\mathrm{kg}) /[\text { height }(\mathrm{m})]^{2}$, representing lean mass index (LMI) and fat mass index (FMI), respectively.

Areal bone mineral density (aBMD) $\left(\mathrm{g} / \mathrm{cm}^{2}\right)$ was evaluated at 22 years of age for the whole body, lumbar spine (L1-L4), and femoral neck.

\section{BMI assessment}

Weight was measured using a balance connected to an air plethysmography displacement unit (BOD $\mathrm{POD}^{\circ}$ Gold Standard - Body Composition Tracking System) with $10 \mathrm{~g}$ precision. Height was measured using a wooden stadiometer with $0.1 \mathrm{~cm}$ precision and a maximum amplitude of $2 \mathrm{~m}$. These measurements were taken by examiners who had been trained and standardized using techniques proposed by Habicht [29]. These variables, in both followups (18 and 22 years), were used to calculate BMI from the ratio of body mass to the square of weight $(\mathrm{kg}) /$ [height $(\mathrm{m})]^{2}$.

\section{Obesity classification}

Obesity was assessed using FMI classification. In both ages, obesity was classified using cutoffs of 9 and $13 \mathrm{~kg} /$ $\mathrm{m}^{2}$ for men and women, respectively [30]. Combination of obesity status at both follow-ups was used to classify individuals' trajectories as "never obese", "obese only at 18 years", "obese only at 22 years", or "always obese".

\section{Covariates}

The following perinatal variables were investigated as potential confounders: mother's educational level $(0-4$, $5-8,9-11, \geq 12$ years of study), family income $(\leq 1 ; 1.1-3$; 
3.1-6; > 6 times the minimum wage), gestational age $(<$ 34; 34-36; 37-40; > 40 weeks), mother's pregestational nutritional status (underweight, healthy weight, overweight, or obese), birth weight (<2500; 2500-2999; 3000$3999 ; \geq 4000 \mathrm{~g}$ ), and birth length (centimeters). Potential confounders collected at 15 years were self-reported skin color (white; black, brown, or other). Confounders at 18 years were smoking habit (at least one cigarette per day during the month prior to the interview), total physical activity (minutes per week), and daily calcium intake (mg, obtained from a food frequency questionnaire).

\section{Statistical analysis}

All statistical analyses were conducted using Stata $12.1^{\circ}$ statistical software (Stata Corp., College Station, Texas, United States) and stratified by sex, since evidence shows that there are sex-linked differences in bone mass $[31,32]$, and tested for significant interactions $(p<0.1)$. The descriptive analysis used absolute and relative frequencies for categorical variables and means and standard deviations (SDs) or medians and interquartile ranges (p25-p75) for numerical variables. Participants included and excluded were compared using the chi-square test (categorical variables), $t$-test, or Wilcoxon Rank Sum Test (numerical variables), depending on normal or nonnormal distribution of data.

Simple and multiple linear regressions were applied to investigate associations between FMI, LMI and BMI (continuous variables, in $\mathrm{kg} / \mathrm{m}^{2}$ ) at each follow-up (at 18 and 22 years of age) and aBMD at 22 years of age. To evaluate the effect according to obesity status at 18 and 22 years on bone mass, simple and multiple linear regressions were also performed, considering "never obese" as a reference category. The association with obesity by FMI was analyzed with an adjustment for LMI. In analyses using continuous exposures, after a test significant $(p<0.001)$ for deviation from linearity between $\mathrm{aBMD}$ and BMI for both sexes and for FMI among the men, a quadratic term was included in the respective adjusted regressions.

Beta coefficients, 95\% confidence intervals (95\% CIs), and $p$ values from the Wald test of heterogeneity were calculated to a statistical significance level of 5\%. When adjusting for possible confounding factors, variables were included in the regressions according to a complete adjustment model irrespective of the level of significance of the association with the outcome in bivariate analysis.

\section{Ethics approval}

All 1993 Pelotas birth cohort follow-ups were approved by the Research Ethics Committee at the Medical Faculty of the Universidade Federal de Pelotas, and the most recent ethics approval protocol is number 1.250.366. At all stages, participants (or their legal guardians) signed free and informed consent forms.

\section{Results \\ Participants studied}

At 18 years of age, 4106 participants were assessed (follow-up rate: $81.3 \%$ ), while at 22 years, 3810 individuals were interviewed (follow-up rate: 76.3\%). Body composition data were available for 2968 of the participants assessed at both follow-ups, of whom 1560 (52.6\%) were female. Table 1 shows the differences between the participants included in this study and the remainder of the cohort. For both sexes, the proportion of participants born with weights in the range 3000-3999g was greater among those included in the study, and so was the proportion of smokers. In contrast, FMI at 18 years and BMI at both follow-ups were both greater among those excluded.

Among men, there was a higher proportion of excluded individuals with family income at birth $\leq 1$ minimum wage, and whole-body bone mass was greater among those included. Among the women, there was a smaller proportion among those included whose mothers had an educational level of $0-4$ years at the time of their birth and a higher proportion of those born at $>40$ weeks than among those excluded. Mean birth length was greater among participants included in the study, whereas mean LMI at 18 and 22 years of age and mean FMI at 22 were greater among those excluded.

\section{Associations between FMI, LMI, BMI and bone mass}

Figure 1 illustrates the associations between FMI, LMI and BMI at 18 and 22 years and bone mass at 22 years of age. Positive effects of all three indices on bone outcomes were observed and were usually largest for the follow-up at 18 years.

For men, the largest coefficients were observed for BMI, followed by lean mass and fat mass. Compared to fat mass, the lean mass presented the largest coefficients for all sites, with the strongest associations observed for the femoral neck ( $\beta: 0.035 \mathrm{~g} / \mathrm{cm}^{2} ; 95 \%$ CI: $0.031 ; 0.039$ for both follow-ups) and whole-body aBMD ( $\beta: 0.026 \mathrm{~g} /$ $\mathrm{cm}^{2}$; 95\% CI: $0.021 ; 0.031$ at 18 years and $\beta: 0.024 \mathrm{~g} / \mathrm{cm}^{2}$; 95\% CI: $0.019 ; 0.029$ at 22 years). The largest effect for FMI was observed for whole-body aBMD at 18 years $(\beta$ : $\left.0.019 \mathrm{~g} / \mathrm{cm}^{2} ; 95 \% \mathrm{CI}: 0.014 ; 0.024\right)$ and lumbar spine, with the same coefficients for both follow-ups ( $\beta: 0.018$ $\mathrm{g} / \mathrm{cm}^{2}$; 95\% CI: 0.013; 0.023).

Among women, lean mass presented the largest coefficients of aBMD gain, with the strongest associations for whole-body ( $\beta: 0.022 \mathrm{~g} / \mathrm{cm}^{2} ; 95 \%$ CI: $0.017 ; 0.027$ for the 18 years and $\beta: 0.019 \mathrm{~g} / \mathrm{cm}^{2} ; 95 \%$ CI: $0.014 ; 0.024$ for the 22 years) and femoral neck sites $\left(\beta: 0.030 \mathrm{~g} / \mathrm{cm}^{2}, 95 \% \mathrm{CI}\right.$ : $0.026,0.034$ for age 18 and $\beta: 0.026 \mathrm{~g} / \mathrm{cm}^{2}, 95 \% \mathrm{CI}$ : $0.022,0.030$ for age 22). For FMI, the largest effect was 
Table 1 Characteristics of participants with complete data at both 18th and 22th-year follow-ups compared with those participants with missing data, loss of follow-up or death, stratified by sex

\begin{tabular}{|c|c|c|c|c|c|c|}
\hline \multirow[t]{4}{*}{ Variables } & \multicolumn{2}{|l|}{ Men } & \multirow{4}{*}{$p$-value } & \multicolumn{2}{|l|}{ Women } & \multirow{4}{*}{$p$-value } \\
\hline & \multicolumn{2}{|c|}{ Mean or median (SD or p25-p75); \% } & & \multicolumn{2}{|c|}{ Mean or median (SD or p25-p75); \% } & \\
\hline & $\begin{array}{l}\text { Participants } \\
\text { included }\end{array}$ & $\begin{array}{l}\text { Participants } \\
\text { excluded' }\end{array}$ & & $\begin{array}{l}\text { Participants } \\
\text { included }\end{array}$ & $\begin{array}{l}\text { Participants } \\
\text { excluded }^{1}\end{array}$ & \\
\hline & $N=1408$ & $N=1195$ & & $N=1560$ & $N=1085$ & \\
\hline \multicolumn{7}{|l|}{ Perinatal } \\
\hline Maternal education (years) & $N=1406$ & $N=1193$ & $0.183^{\mathrm{a}}$ & $N=1557$ & $N=1085$ & $0.003^{\mathrm{a}}$ \\
\hline $0-4$ & 25.3 & 29.2 & & 26.7 & 32.0 & \\
\hline $5-8$ & 47.6 & 45.3 & & 46.4 & 45.2 & \\
\hline $9-11$ & 18.6 & 17.5 & & 19.0 & 14.5 & \\
\hline$\geq 12$ & 8.5 & 8.0 & & 7.9 & 8.3 & \\
\hline Family income (MMW) & $N=1388$ & $N=1159$ & $0.039^{a}$ & $N=1528$ & $N=970$ & $0.272^{\mathrm{a}}$ \\
\hline$\leq 1$ & 17.9 & 20.6 & & 17.3 & 20.3 & \\
\hline $1.1-3$ & 42.4 & 42.3 & & 41.6 & 40.6 & \\
\hline $3.1-6$ & 24.4 & 20.2 & & 24.9 & 23.5 & \\
\hline$>6$ & 15.3 & 16.9 & & 16.2 & 15.6 & \\
\hline Gestational age (weeks) & $N=1391$ & $N=1159$ & $0.321^{\mathrm{a}}$ & $N=1539$ & $N=1050$ & $0.002^{\mathrm{a}}$ \\
\hline$<34$ & 1.2 & 2.0 & & 1.2 & 2.9 & \\
\hline $34-36$ & 6.2 & 6.4 & & 7.8 & 6.7 & \\
\hline $37-40$ & 75.8 & 76.1 & & 77.2 & 79.3 & \\
\hline$>40$ & 16.8 & 15.5 & & 13.8 & 11.1 & \\
\hline Maternal nutritional status (BMI) & $N=1366$ & $N=1155$ & $0.182^{\mathrm{a}}$ & $N=1530$ & $N=1046$ & $0.237^{\mathrm{a}}$ \\
\hline Low weight & 10.4 & 9.1 & & 8.0 & 7.8 & \\
\hline Adequate & 67.3 & 69.7 & & 67.6 & 71.3 & \\
\hline Overweight & 17.9 & 15.7 & & 19.4 & 16.5 & \\
\hline Obese & 4.4 & 5.5 & & 5.0 & 4.4 & \\
\hline Birth weight (grams) & $N=1407$ & $N=1188$ & $0.017^{\mathrm{a}}$ & $N=1559$ & $N=1078$ & $<0.001^{\mathrm{a}}$ \\
\hline$<2500$ & 7.5 & 10.1 & & 10.9 & 10.6 & \\
\hline 2500-2999 & 22.5 & 19.2 & & 26.1 & 33.4 & \\
\hline 3000-3999 & 64.0 & 63.3 & & 59.2 & 53.6 & \\
\hline$\geq 4000$ & 6.0 & 7.4 & & 3.8 & 2.4 & \\
\hline \multirow[t]{2}{*}{ Length at birth (centimeters) } & $N=1395$ & $N=1165$ & $0.901^{\mathrm{b}}$ & $N=1548$ & $N=1054$ & $0.029^{b}$ \\
\hline & $49.1(2.3)$ & $49.1(2.6)$ & & $48.5(2.3)$ & $48.3(2.3)$ & \\
\hline \multicolumn{7}{|l|}{15 years } \\
\hline Skin color & $N=1345$ & $N=765$ & $0.108^{\mathrm{a}}$ & $N=1540$ & $N=673$ & $0.597^{\mathrm{a}}$ \\
\hline White & 63.0 & 66.5 & & 63.4 & 64.6 & \\
\hline Black, brown or other & 37.0 & 33.5 & & 36.6 & 35.4 & \\
\hline \multicolumn{7}{|l|}{18 years } \\
\hline Smoking habit & $N=1408$ & $N=606$ & $0.015^{\mathrm{a}}$ & $N=1560$ & $N=531$ & $0.005^{\mathrm{a}}$ \\
\hline No & 86.0 & 81.7 & & 88.2 & 83.2 & \\
\hline Yes & 14.0 & 18.3 & & 11.8 & 16.8 & \\
\hline \multirow[t]{2}{*}{ Total physical activity (min/week) } & $N=1406$ & $N=602$ & $0.203^{c}$ & $N=1559$ & $N=528$ & $0.966^{c}$ \\
\hline & $630.0(300.01110 .0)$ & $592.5(260.0 ; 1140.0)$ & & $270.0(110.0 ; 600.0)$ & $280.0(120.0 ; 600.0)$ & \\
\hline \multirow[t]{2}{*}{ Total calcium consumption (mg) } & $N=1406$ & $N=587$ & $0.282^{c}$ & $N=1559$ & $N=517$ & $0.656^{\mathrm{c}}$ \\
\hline & $674.8(488.9 ; 939.4)$ & $670.6(479.5 ; 897.8)$ & & $638.1(449.3 ; 922.1)$ & $660.2(477.4 ; 891.4)$ & \\
\hline
\end{tabular}


Table 1 Characteristics of participants with complete data at both 18th and 22th-year follow-ups compared with those participants with missing data, loss of follow-up or death, stratified by sex (Continued)

\begin{tabular}{|c|c|c|c|c|c|c|}
\hline \multirow[t]{4}{*}{ Variables } & \multicolumn{2}{|l|}{ Men } & & \multicolumn{2}{|l|}{ Women } & \multirow{4}{*}{$p$-value } \\
\hline & \multicolumn{2}{|c|}{ Mean or median (SD or p25-p75); \% } & \multirow{3}{*}{$p$-value } & \multicolumn{2}{|c|}{ Mean or median (SD or p25-p75); \% } & \\
\hline & $\begin{array}{l}\text { Participants } \\
\text { included }\end{array}$ & $\begin{array}{l}\text { Participants } \\
\text { excluded }\end{array}$ & & $\begin{array}{l}\text { Participants } \\
\text { included }\end{array}$ & $\begin{array}{l}\text { Participants } \\
\text { excluded }^{1}\end{array}$ & \\
\hline & $N=1408$ & $N=1195$ & & $N=1560$ & $N=1085$ & \\
\hline \multirow[t]{2}{*}{ Lean mass index $\left(\mathrm{kg} / \mathrm{m}^{2}\right)$} & $N=1408$ & $N=493$ & $0.281^{b}$ & $N=1560$ & $N=390$ & $0.002^{b}$ \\
\hline & $18.0(1.5)$ & $18.0(1.7)$ & & $14.0(1.4)$ & $14.3(1.6)$ & \\
\hline \multirow[t]{2}{*}{ Fat mass index $\left(\mathrm{kg} / \mathrm{m}^{2}\right)$} & $N=1408$ & $N=493$ & $0.012^{b}$ & $N=1560$ & $N=390$ & $<0.001^{\mathrm{b}}$ \\
\hline & $4.1(2.9)$ & $4.5(3.5)$ & & $8.3(3.5)$ & $9.0(3.9)$ & \\
\hline \multirow[t]{2}{*}{ Body mass index $\left(\mathrm{kg} / \mathrm{m}^{2}\right)$} & $N=1408$ & $N=570$ & $<0.001^{\mathrm{b}}$ & $N=1560$ & $N=449$ & $<0.001^{\mathrm{b}}$ \\
\hline & $23.0(3.6)$ & $24.2(5.5)$ & & $23.2(4.4)$ & $24.6(5.8)$ & \\
\hline \multicolumn{7}{|l|}{22 years } \\
\hline \multirow[t]{2}{*}{ Lean mass index $\left(\mathrm{kg} / \mathrm{m}^{2}\right)$} & $N=1408$ & $N=133$ & $0.185^{b}$ & $N=1560$ & $N=217$ & $<0.001^{\mathrm{b}}$ \\
\hline & $18.2(1.7)$ & $18.0(2.0)$ & & $14.3(1.7)$ & $14.8(1.9)$ & \\
\hline \multirow[t]{2}{*}{ Fat mass index $\left(\mathrm{kg} / \mathrm{m}^{2}\right)$} & $N=1408$ & $N=133$ & $0.571^{b}$ & $N=1560$ & $N=217$ & $<0.001^{\mathrm{b}}$ \\
\hline & $5.5(3.4)$ & $5.7(4.0)$ & & $9.8(4.1)$ & $11.0(5.0)$ & \\
\hline \multirow[t]{2}{*}{ Body mass index $\left(\mathrm{kg} / \mathrm{m}^{2}\right)$} & $N=1408$ & $N=279$ & $<0.001^{b}$ & $N=1560$ & $N=315$ & $<0.001^{\mathrm{b}}$ \\
\hline & $24.7(4.2)$ & $26.2(6.7)$ & & $25.1(5.3)$ & $27.3(7.3)$ & \\
\hline \multirow[t]{2}{*}{ Whole body BMD $\left(\mathrm{g} / \mathrm{cm}^{2}\right)$} & $N=1408$ & $N=139$ & $0.041^{b}$ & $N=1560$ & $N=221$ & $0.532^{b}$ \\
\hline & $1.3(0.1)$ & $1.2(0.1)$ & & $1.2(0.1)$ & $1.2(0.1)$ & \\
\hline \multirow[t]{2}{*}{ Lumbar spine BMD $\left(\mathrm{g} / \mathrm{cm}^{2}\right)$} & $N=1408$ & $N=164$ & $0.542^{b}$ & $N=1560$ & $N=220$ & $0.886^{\mathrm{b}}$ \\
\hline & $1.2(0.1)$ & $1.2(0.2)$ & & $1.2(0.1)$ & $1.2(0.1)$ & \\
\hline \multirow[t]{2}{*}{ Femoral neck BMD $\left(\mathrm{g} / \mathrm{cm}^{2}\right)$} & $N=1408$ & $N=164$ & $0.187^{b}$ & $N=1560$ & $N=220$ & $0.355^{\mathrm{b}}$ \\
\hline & $1.2(0.2)$ & $1.2(0.2)$ & & $1.0(0.1)$ & $1.0(0.1)$ & \\
\hline \multicolumn{7}{|l|}{ Outcome changes $(\Delta)$ at $18-22$ years* } \\
\hline \multirow[t]{2}{*}{ Whole body BMD change $\left(\mathrm{g} / \mathrm{cm}^{2}\right)$} & $N=1408$ & $N=12$ & $0.174^{c}$ & $N=1560$ & $N=10$ & $0.241^{c}$ \\
\hline & $0.04(0.02 ; 0.07)$ & $0.04(0.01 ; 0.05)$ & & $0.02(0.01 ; 0.04)$ & $0.04(0.02 ; 0.06)$ & \\
\hline \multirow{2}{*}{$\begin{array}{l}\text { Lumbar spine BMD change }(\mathrm{g} / \\
\left(\mathrm{Cm}^{2}\right)\end{array}$} & $N=1406$ & $N=62$ & $0.514^{c}$ & $N=1558$ & $N=32$ & $0.980^{c}$ \\
\hline & $0.06(0.02 ; 0.10)$ & $0.05(0.01 ; 0.09)$ & & $0.04(0.01 ; 0.07)$ & $0.04(0.01 ; 0.07)$ & \\
\hline \multirow{2}{*}{$\begin{array}{l}\text { Femoral neck BMD change }(\mathrm{g} / \\
\mathrm{cm}^{2} \text { ) }\end{array}$} & $N=1407$ & $N=59$ & $0.486^{c}$ & $N=1547$ & $N=43$ & $0.412^{c}$ \\
\hline & $0.01(-0.05 ; 0.06)$ & $0.02(-0.04 ; 0.07)$ & & $0.01(-0.03 ; 0.05)$ & $0.02(-0.02 ; 0.10)$ & \\
\hline
\end{tabular}

$N$ Number of observations, $S D$ standard deviation, \% percentage, $M M W$ monthly minimum wages, $B M I$ body mass index, $B M D$ bone mineral density ( $\mathrm{g} / \mathrm{m}^{2}$ )

*Changes in measurement of BMD at $22 y-$ at $18 y$

${ }^{1}$ Participants excluded from the analyses due to loss of follow-up or missing data;

${ }^{a} P$ value refers to $\mathrm{Chi}$-squared heterogeneity test;

${ }^{b} P$ value refers to Student's t-test;

${ }^{c} P$ value refers to Wilcoxon Rank Sum Test

The 1993 Pelotas Birth Cohort, Brazil

observed at 18 years for all sites, with strongest associations for femoral neck ( $\beta$ : $0.012 \mathrm{~g} / \mathrm{cm}^{2} ; 95 \% \mathrm{CI}: 0.009$; $0.015)$ followed by lumbar spine $\left(\beta: 0.011 \mathrm{~g} / \mathrm{cm}^{2} ; 95 \% \mathrm{CI}\right.$ : $0.008 ; 0.014)$ and whole-body aBMD $\left(\beta: 0.010 \mathrm{~g} / \mathrm{cm}^{2}\right.$; 95\% CI: 0.007; 0.013).

\section{Association between obesity and bone mass}

Table 2 describes the relationship between obesity, classified by FMI from 18 to 22 years and bone mass at 22 years of age, showing that among men who were "obese" at both follow-ups, there was a reduction in lumbar spine aBMD compared to the reference category $(\beta$ : $\left.0.014 \mathrm{~g} / \mathrm{cm}^{2} ; 95 \% \mathrm{CI}:-0.029 ;-0.001\right)$. Among women, those who were obese "only at 18 years" of age presented a reduction in whole-body aBMD $\left(\beta:-0.013 \mathrm{~g} / \mathrm{cm}^{2} ; 95 \%\right.$ CI: $-0.023 ;-0.002)$, whereas those who were obese "only at 22 years" and "always obese" presented an increase in whole-body aBMD $\left(\beta: 0.013 \mathrm{~g} / \mathrm{cm}^{2} ; 95 \% \mathrm{CI}\right.$ : 0.009; 0.017 and $\beta: 0.005 \mathrm{~g} / \mathrm{cm}^{2}$; 95\% CI: 0.001; 0.011, respectively). For femoral neck aBMD, women obese "only 


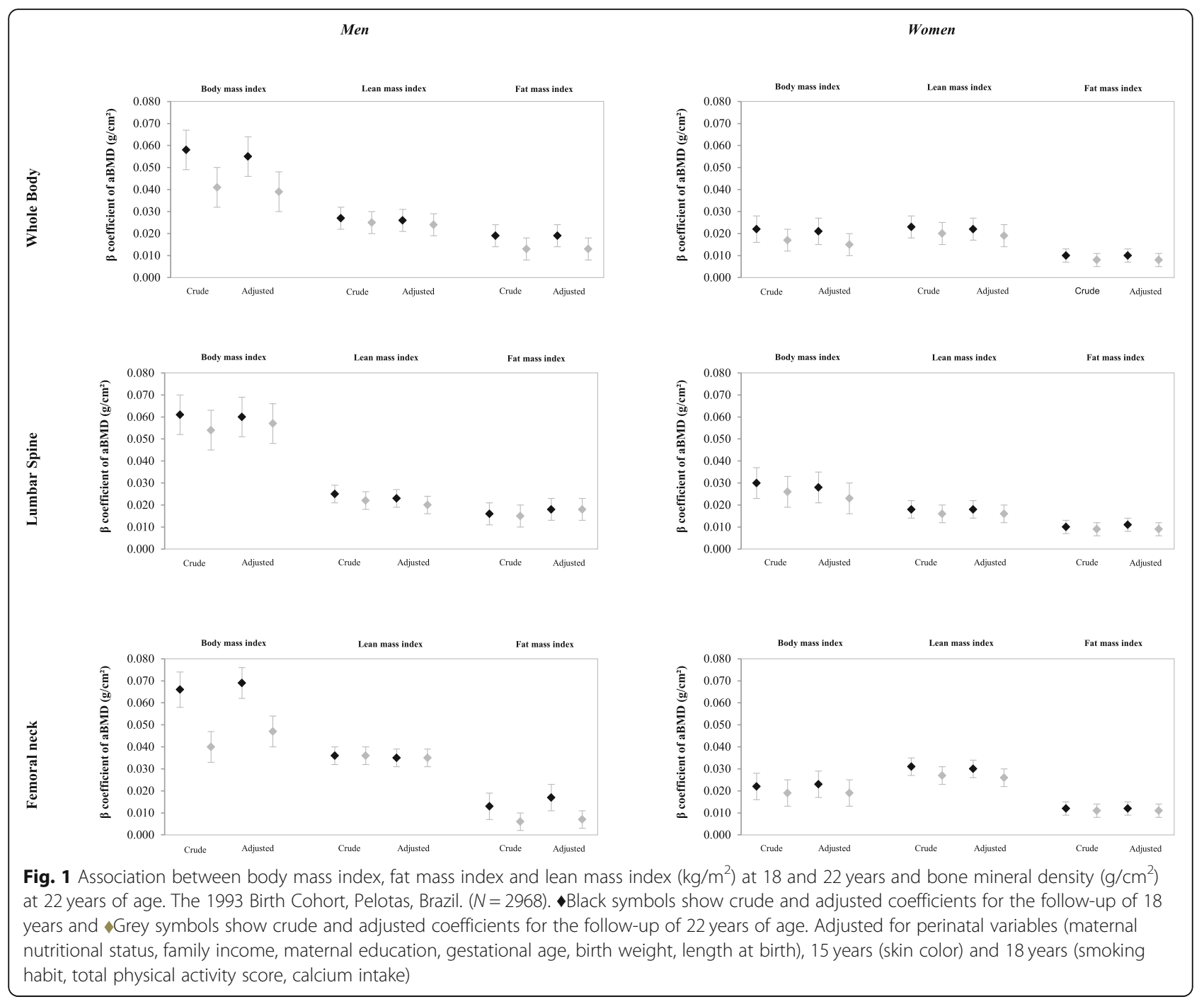

at 22 years" had a mean increase of $0.027 \mathrm{~g} / \mathrm{cm}^{2}$ (95\% CI: $0.016 ; 0.038)$, compared to those "never obese".

\section{Discussion}

This study investigated the effect of body composition components (FMI and LMI) and BMI at 18 and 22 years and trajectory of obesity on bone density at 22 years. Our results suggest that despite the effect of BMI on bone mass, the impact of lean mass and fat mass differed, with a largest effect observed for lean mass. For both body composition components, the strongest associations were observed at 18 years. According to obesity classification, there was a negative effect in the lumbar spine among men who were "always obese". For women, the negative effect was observed in the whole body between those who was obese "only at 18 years". Between those who was obese "only at 22 years" and "always obese" presented a density increase in whole-body and femoral neck.
According to the literature, at age 18, approximately $90 \%$ of the bone mass will have been accumulated [33]. The remainder of BMD accumulation occurs during late adolescence, up to the age of 21-25 years. The exact age at which bone accumulation reaches a plateau varies with sex and the region of the skeleton [34]. The peak bone mass of the proximal femur sites occurs around the age of 20 years, while the total body mass reaches its peak between 6 and 10 years later [35]. Many studies have estimated peak bone mass from cross-sectional data [36-38], and others have assessed the longitudinal change [39-42], but only a few have used longitudinal assessment in a population-based sample including teens and young adults $[34,43]$.

Berger et al. (2010) found that most bone accumulation, especially of the spine and hip, occurs before age 16 in men and women, with more than $94 \%$ of peak bone mass already reached by that age [34]. Lu et al. (2016), however, observed that total accumulation ranged from early to late 
Table 2 Association between obesity according to Fat Mass Index (FMI) from 18 to 22 years on bone mineral density $\left(\mathrm{g} / \mathrm{cm}^{2}\right)$ at 22 years of age

\begin{tabular}{|c|c|c|c|c|c|c|c|}
\hline \multirow[t]{4}{*}{ Variable } & \multicolumn{7}{|c|}{ Men $(N=1408)$} \\
\hline & \multirow[t]{3}{*}{$\mathrm{N}$} & \multicolumn{2}{|l|}{ Whole Body } & \multicolumn{2}{|l|}{ Lumbar Spine } & \multicolumn{2}{|l|}{ Femoral Neck } \\
\hline & & Mean & Adjusted $^{a}$ & Mean & Adjusted $^{a}$ & Mean & Adjusted $^{a}$ \\
\hline & & $(95 \% \mathrm{Cl})$ & $\beta(95 \% \mathrm{Cl})$ & $(95 \% \mathrm{Cl})$ & $\beta(95 \% \mathrm{Cl})$ & $(95 \% \mathrm{Cl})$ & $\beta(95 \% \mathrm{Cl})$ \\
\hline Obesity by FMl & & & 0.332 & & 0.140 & & 0.088 \\
\hline \multirow[t]{2}{*}{ Never } & 1139 & 1.263 & Reference & 1.232 & Reference & 1.169 & Reference \\
\hline & & $(1.257 ; 1.268)$ & & $(1.224 ; 1.241)$ & & $(1.159 ; 1.179)$ & \\
\hline \multirow[t]{2}{*}{ Only at 18 years } & 28 & 1.297 & 0.008 & 1.304 & 0.007 & 1.188 & 0.021 \\
\hline & & $(1.263 ; 1.331)$ & $(-0.020 ; 0.005)$ & $(1.251 ; 1.357)$ & $(-0.016 ; 0.031)$ & $(1.128 ; 1.249)$ & $(-0.013 ; 0.055)$ \\
\hline \multirow[t]{2}{*}{ Only at 22 years } & 158 & 1.300 & 0.002 & 1.249 & -0.007 & 1.204 & 0.015 \\
\hline & & $(1.286 ; 1.313)$ & $(-0.004 ; 0.008)$ & $(1.228 ; 1.270)$ & $(-0.017 ; 0.004)$ & $(1.179 ; 1.228)$ & $(-0.001 ; 0.030)$ \\
\hline \multirow[t]{2}{*}{ Always } & 83 & 1.313 & 0.005 & 1.242 & -0.014 & 1.208 & 0.018 \\
\hline & & $(1.295 ; 1.331)$ & $(-0.003 ; 0.012)$ & $(1.216 ; 1.268)$ & $(-0.029 ;-0.001)$ & $(1.175 ; 1.241)$ & $(-0.003 ; 0.038$ \\
\hline \multirow[t]{4}{*}{ Variable } & \multicolumn{7}{|c|}{ Women $(N=1560)$} \\
\hline & \multirow[t]{3}{*}{ N } & \multicolumn{2}{|l|}{ Whole Body } & \multicolumn{2}{|l|}{ Lumbar Spine } & \multicolumn{2}{|l|}{ Femoral Neck } \\
\hline & & Mean & Adjusted $^{a}$ & Mean & Adjusted $^{a}$ & Mean & Adjusted $^{a}$ \\
\hline & & $(95 \% \mathrm{Cl})$ & $\beta(95 \% \mathrm{Cl})$ & $(95 \% \mathrm{Cl})$ & $\beta(95 \% \mathrm{Cl})$ & $(95 \% \mathrm{Cl})$ & $\beta(95 \% \mathrm{Cl})$ \\
\hline Obesity by FMl & & & $<0.001$ & & 0.339 & & 0.001 \\
\hline \multirow[t]{2}{*}{ Never } & 1208 & 1.142 & Reference & 1.185 & Reference & 1.007 & Reference \\
\hline & & $(1.138 ; 1.146)$ & & $(1.178 ; 1.192)$ & & $(1.000 ; 1.014)$ & \\
\hline \multirow[t]{2}{*}{ Only at 18 years } & 23 & 1.183 & -0.013 & 1.239 & -0.005 & 1.036 & -0.014 \\
\hline & & $(1.153 ; 1.212)$ & $(-0.023 ;-0.002)$ & $(1.192 ; 1.285)$ & $(-0.027 ; 0.018)$ & $(0.989 ; 1.083)$ & $(-0.042 ; 0.014$ \\
\hline \multirow[t]{2}{*}{ Only at 22 years } & 182 & 1.192 & 0.013 & 1.228 & 0.007 & 1.080 & 0.027 \\
\hline & & $(1.182 ; 1.202)$ & $(0.009 ; 0.017)$ & $(1.210 ; 1.247)$ & $(-0.001 ; 0.016)$ & $(1.063 ; 1.097)$ & $(0.016 ; 0.038)$ \\
\hline \multirow[t]{2}{*}{ Always } & 147 & 1.236 & 0.005 & 1.286 & -0.001 & 1.129 & 0.006 \\
\hline & & $(1.225 ; 1.248)$ & $(0.001 ; 0.011)$ & $(1.266 ; 1.305)$ & $(-0.012 ; 0.010)$ & $(1.109 ; 1.149)$ & $(-0.008 ; 0.019)$ \\
\hline
\end{tabular}

${ }^{a}$ Adjusted for perinatal variables (maternal nutritional status, family income, maternal education, gestational age, weight and length), 15 years (skin color), 18 years (smoking, total physical activity score, calcium intake) and 22 years of age (lean mass index)

The 1993 Birth Cohort, Pelotas, Brazil

20s for both sexes, with women reaching their peaks significantly earlier [43]. Additionally, weight, height and BMI had a significant effect on bone tracking [43]. These results indicate that early intervention before and during puberty is necessary to achieve optimal peak bone mass.

The present study confirms that the body composition components affect bone mass with unequal magnitude in an important period of bone accumulation before reaching peak bone mass. This is important because attaining a high peak bone mass in early life predicts a higher bone mass and a reduced risk of osteopenia or osteoporosis later in life [1]. The effects are probably due to different causes, through mechanisms that go beyond the effect of the direct load on the skeleton [15]; genetic, environmental, and hormonal factors are also involved [44-46].

The literature shows that obesity in adulthood can be protective against osteoporotic fractures [9, 10, 18, 47], whereas at younger ages, obesity can have negative effects that are specific to bone [11, 18, 22-24]. Differences in age, severity, and duration of obesity, particularly among longitudinal studies of the subject [48-50], may explain these conflicting results [49-51]. In the current study, the obesity classification revealed a negative association with aBMD in men. Among women, although most of the observed effects were positive, a negative effect was observed among those obese "only at 18 years". It should be highlighted that this analysis was adjusted for LMI when obesity was classified by FMI, thereby removing the effect of this component. Besides, in both sexes, most of the effects were largest when evaluated at 18 years, showing a lag time between these measures of body composition and bone mass. To confirm this, we performed a transversal analysis to assess the effect of LMI, FMI and BMI at age 18 , on bone mass also at 18 years. We can observe that the magnitude of this transversal association was lower, 
mainly for FMI and BMI exposures (data not shown), reinforcing the existence of this latency period. We also performed analyses on the effect of 18-year exposures on change in bone mass between 18 and 22 years, and we found a positive effect for the whole body, but negative effects could be observed for the sites of the spine and femoral neck.

In addition to mechanical loading, adipose tissue can have an indirect positive effect on bone metabolism via adipokine, cytokines and hormones and can stimulate bone formation by producing estrogens from steroid precursors, increasing the levels of leptin and insulin in the circulation [52-55]. However, adipose tissue also produces adiponectin and cytokines related to inflammation, such as tumor necrosis factor $\alpha$ (TNF- $\alpha$ ) and interleukin 6 (IL-6), which can have harmful effects on the bones $[52-54,56]$. In the present study, we observed a positive effect of FMI, although it was visibly inferior to that observed for LMI, which leads us to suppose that the small duration of time elapsed between collection of exposure and outcome data may have prevented the manifestation of the negative effect of body fat.

Evidence points to the existence of an FM threshold that, if exceeded during critical periods of skeletal development - particularly in adolescence - may result in skeletal fragility and ultimately a greater risk of fracture $[3,20,57,58]$. Measures of bone content, density, and strength improve to the extent that LM and FM increase until a "fat threshold" is reached, beyond which additional fat has harmful effects on the growing skeleton $[58,59]$. According to a recent meta-analysis, a greater negative correlation between relative adiposity (in percentages) and bone density was observed in obese people $(r=-0.20)$ than in those who were overweight $(r=-0.08)$, indicating that the negative impact of adiposity on BMD increases to the extent that adiposity progresses from the overweight category to obese levels, which was particularly evident among men and among those under the age of 25 years [24].

The present study has important strengths, such as aBMD measurements obtained using DXA, the gold standard for bone mass evaluation; a high follow-up rate; the possibility of assessing the association between obesity and bone mass adjusted for potential confounding factors assessed prospectively over the life course, e.g., maternal characteristics at birth and maternal nutritional status; and measurement of exposure at two points in time.

The main limitation of the present study is the short time period investigated. However, in the 1993 cohort, body composition was first evaluated at 18 years of age. We encourage studies of younger cohorts to include the assessment of body composition at early stages to better explore the longer effects of body composition on bone health, including subsequent follow-ups of the 1993 cohort. This recommendation is further justified by the fact that the literature on this topic generally evaluates the relationship between body composition and bone mass in older populations [60-62] and in premenopausal and postmenopausal women $[15,63,64]$. Another limitation is the lack of data on peak bone growth in our population.

\section{Conclusions}

This study observed positive effects of FMI and LMI on bone density at 22 years, with a largest effect observed for lean mass. For both body composition components, the strongest associations were observed at 18 years. According to obesity classification, some negative effects were found at 22 years. These findings emphasize that the body composition components have different effects on bone mass and raise questions about the effects of fat mass at young ages, especially whether the longer time of adiposity exposure may have harmful consequences for bone health.

\section{Abbreviations \\ 95\% Cl: 95\% confidence intervals; aBMD: Areal bone mineral density; BMD: Bone mineral density; BMI: Body mass index; DXA: Dual-energy X-ray absorptiometry; FM: Fat mass; FMI: Fat mass index; IL-6: interleukin 6; LM: Lean mass; LMI: Lean mass index; MMW: monthly minimum wages; REDCap: Research Electronic Data Capture; SD: standard deviations; TNF- a: tumor necrosis factor a; WHO: World Health Organization}

\section{Acknowledgements}

Not applicable.

\section{Authors' contributions}

IOB, JSV and MCFA designed research; IOB performed statistical analyses; IOB, JSV, RMB and MCFA wrote the paper. JSV, MCFA, RMB. CLM, FCB, HG and FCW reviewed all the drafts of the manuscript and contributed with suggestions to the work. IOB, JV and MCFA had primary responsibility for final content. All authors read and approved the final manuscript.

\section{Funding}

This article is based on data from the study "Pelotas Birth Cohort, 1993" conducted by Postgraduate Program in Epidemiology at Universidade Federal de Pelotas with the collaboration of the Brazilian Public Health Association (ABRASCO). From 2004 to 2013, the Wellcome Trust supported the 1993 birth cohort study. The European Union, National Support Program for Centers of Excellence (PRONEX), the Brazilian National Research Council (CNPq), and the Brazilian Ministry of Health supported previous phases of the study. The 22-year follow-up was supported by the Science and Technology Department/Brazilian Ministry of Health, with resources transferred through the Brazilian National Council for Scientific and Technological Development (CNPq), grant 400943/2013-1.

This study was financed in part by the Coordenação de Aperfeiçoamento de Pessoal de Nível Superior - Brasil (CAPES) - Finance Code 001.

\section{Availability of data and materials}

The datasets used and/or analyzed during the current study are available from the corresponding author on reasonable request.

\section{Ethics approval and consent to participate}

All the follow-ups of the 1993 Pelotas Birth Cohort Study were approved by the Research Ethics Committee of the Federal University of Pelotas Medical School under permit number 1.250.366. At all stages, the participants (or their legal guardians up to 15 years old follow-up) signed an informed consent form. 


\section{Consent for publication}

Not applicable.

\section{Competing interests}

The authors declare that they have no competing interests.

Received: 22 January 2019 Accepted: 27 May 2019

Published online: 09 July 2019

\section{References}

1. Heaney RP, Abrams S, Dawson-Hughes B, Looker A, Marcus R, Matkovic V, et al. Peak bone mass. Osteoporos Int. 2000;11(12):985-1009.

2. Hernandez CJ, Beaupré GS, Carter DR. A theoretical analysis of the relative influences of peak BMD, agerelated bone loss and menopause on the development of osteoporosis. Osteoporos Int. 2003:14(10):843-7.

3. Dimitri P. Fat and bone in children - where are we now? Ann Pediatr Endocrinol Metab. 2018:23:262-9.

4. Savvidis C, Tournis S, Dede AD. Obesity and bone metabolism. Hormones. 2018;17(2):205-17.

5. Hwang LC, Bai CH, Sun CA, Chen CJ. Prevalence of metabolically healthy obesity and its impacts on incidences of hypertension, diabetes and the metabolic syndrome in Taiwan. Asia Pac J Clin Nutr. 2012;21(2):227-33.

6. Phillips CM, Dillon C, Harrington JM, McCarthy VJ, Kearney PM, Fitzgerald AP, et al. Defining metabolically healthy obesity: role of dietary and lifestyle factors. PLoS One. 2013;8(10):e76188.

7. Swinburn BA, Sacks G, Hall KD, McPherson K, Finegood DT, Moodie ML, et al. The global obesity pandemic: shaped by global drivers and local environments. Lancet. 2011;378(9793):804-14.

8. Wang CY, McPherson K, Marsh T, Gortmaker SL, Brown M. Health and economic burden of the projected obesity trends in the USA and the UK. Lancet. 2011;378(9793):815-25.

9. De Laet C, Kanis JA, Oden A, Johanson H, Johnell O, Delmas P, et al. Body mass index as a predictor of fracture risk: a meta-analysis. Osteoporos Int. 2005;16(11):1330-8.

10. Lloyd JT, Alley DE, Hawkes WG, Hochberg MC, Waldstein SR, Orwig DL. Body mass index is positively associated with bone mineral density in US older adults. Arch Osteoporos. 2014:9:175.

11. Mosca LN, Goldberg TB, Da Silva VN, Da Silva CC, Kurokawa CS, Bisi Rizzo $A C$, et al. Excess body fat negatively affects bone mass in adolescents. Nutrition. 2014;30(7-8):847-52.

12. Winther A, Dennison E, Ahmed LA, Furberg AS, Grimnes G, Jorde R, et al. The Tromso study: fit futures: a study of Norwegian adolescents' lifestyle and bone health. Arch Osteoporos. 2014;9(1):185.

13. Leonard MB, Shults J, Wilson BA, Tershakovec AM, Zemel BS. Obesity during childhood and adolescence augments bone mass and bone dimensions. Am J Clin Nutr. 2004;80(2):514-23.

14. Mosca LN, Da Silva VN, Goldberg TB. Does excess weight interfere with bone mass accumulation during adolescence? Nutrients. 2013;5(6):2047-61.

15. Kim J, Kwon H, Heo BK, Joh HK, Lee CM, Hwang SS, et al. The association between fat mass, lean mass and bone mineral density in premenopausal women in Korea: a cross-sectional study. Korean J Fam Med. 2018;39(2):74-84.

16. Ho-Pham LT, Nguyen UD, Nguyen TV. Association between lean mass, fat mass, and bone mineral density: a meta-analysis. J Clin Endocrinol Metab. 2014:99(1):30-8.

17. Sioen I, Lust E, De Henauw S, Moreno LA, Jiménez-Pavón D. Associations between body composition and bone health in children and adolescents: a systematic review. Calcif Tissue Int. 2016;99(6):557-77.

18. Dimitri P, Bishop N, Walsh JS, Eastell R. Obesity is a risk factor for fracture in children but is protective against fracture in adults: a paradox. Bone. 2012; 50(2):457-66.

19. Weaver CM, Gordon CM, Janz KF, Kalkwarf HJ, Lappe JM, Lewis R, et al. The National Osteoporosis Foundation's position statement on peak bone mass development and lifestyle factors: a systematic review and implementation recommendations. Osteoporos Int. 2016;27(4):1281-386.

20. Wey HE, Binkley TL, Beare TM, Wey CL, Specker BL. Cross-sectional versus longitudinal associations of lean and fat mass with PQCT bone outcomes in children. J Clin Endocrinol Metab. 2011;96(1):106-14.

21. Compston JE, Watts NB, Chapurlat R, Cooper C, Boonen S, Greenspan S, et al. Obesity is not protective against fracture in postmenopausal women: GLOW. Am J Med United States. 2011;124(11):1043-50.
22. Janicka A, Wren TA, Sanchez MM, Dorey F, Kim PS, Mittelman SD, et al. Fat mass is not beneficial to bone in adolescents and young adults. J Clin Endocrinol Metab. 2007;92(1):143-7.

23. Russell M, Mendes N, Miller KK, Rosen CJ, Lee H, Klibanski A, et al. Visceral fat is a negative predictor of bone density measures in obese adolescent girls. J Clin Endocrinol Metab. 2010;95(2):1247-55.

24. Dolan E, Swinton PA, Sale C, Healy A, O'Reilly J. Influence of adipose tissue mass on bone mass in an overweight or obese population: systematic review and meta-analysis. Nutr Rev. 2017;75(10):858-70.

25. Victora CG, Hallal PC, Araújo CLP, Menezes AMB, Wells JCK, Barros FC. Cohort profile: the 1993 Pelotas (Brazil) birth cohort study. Int J Epidemiol. 2008:37:704-9.

26. Gonçalves H, Assunção MCF, Wehrmeister FC, Oliveira IO, Barros FC, Victora CG, et al. Cohort profile update: the 1993 Pelotas (Brazil) birth cohort followup visits in adolescence. Int J Epidemiol. 2014:43:1-7.

27. Gonçalves H, Wehrmeister FC, Assunção MCF, Tovo-Rodrigues L, Oliveira IO, Murray J, et al. Cohort profile update: the 1993 Pelotas (Brazil) birth cohort follow-up at 22 years. Int J Epidemiol. 2017:1-7.

28. Harris PA, Taylor R, Thielke R, Payne J, Gonzales N, Conde JG. Research electronic data capture (REDCap) - a metadata-driven methodology and workflow process for providing translational research informatics support. J Biomed Inform. 2009;42(2):377-81.

29. Habicht JP. Estandartización de métodos epidemiológicos quantitativos sobre el terreno. Bol Oficina Sanit Panam. 1974;76:375-84.

30. Kelly $\mathrm{TL}$, Wilson KE, Heymsfield SB. Dual energy X-ray absorptiometry body composition reference values from NHANES. PLoS One. 2009;4(9):e7038.

31. Leonard MB, Elmi A, Mostoufi-Moab S, Shults J, Burnham JM, Thayu M, et al. Effects of sex, race, and puberty on cortical bone and the functional muscle bone unit in children, adolescents, and young adults. J Clin Endocrinol Metab. 2010:95(4):1681-8.

32. Alswat KA. Gender Disparities in Osteoporosis. J Clin Med Res. 2017;9(5):382-7.

33. Bachrach LK. Acquisition of optimal bone mass in childhood and adolescence. Trends Endocrinol Metab. 2001;12(1):22-8.

34. Berger C, Goltzman D, Langsetmo L, Joseph L, Jackson S, Kreiger N, et al. Peak bone mass from longitudinal data: implications for the prevalence, pathophysiology, and diagnosis of osteoporosis. J Bone Miner Res. 2010; 25(9):1948-57.

35. Matkovic V, Jelic T, Wardlaw GM, llich JZ, Goel PK, Wright JK, et al. Timing of peak bone mass in Caucasian females and its implication for the prevention of osteoporosis. Inference from a cross-sectional model. J Clin Invest. 1994; 93(2):799-808.

36. Høiberg M, Nielsen TL, Wraae K, Abrahamsen B, Hagen C, Andersen M, et al. Population-based reference values for bone mineral density in young men. Osteoporos Int. 2007;18(11):1507-14.

37. Henry MJ, Pasco JA, Korn S, Gibson JE, Kotowicz MA, Nicholson GC. Bone mineral density reference ranges for Australian men: Geelong osteoporosis study. Osteoporos Int. 2010;21:909-17.

38. Ribom EL, Ljunggren $\mathrm{O}$, Mallmin $\mathrm{H}$. Use of a Swedish T-score reference population for women causes a two-fold increase in the amount of postmenopausal Swedish patients that fulfill the WHO criteria for osteoporosis. J Clin Densitom. 20008;11(3):404-11.

39. Bachrach LK, Hastie T, Wang MC, Narasimhan B, Marcus R. Bone minera acquisition in healthy Asian, Hispanic, black, and Caucasian youth: a longitudinal study. J Clin Endocrinol Metab. 1999;84(12):4702-12.

40. Mein AL, Briffa NK, Dhaliwal SS, Price RI. Lifestyle influences on 9-year changes in BMD in young women. J Bone Miner Res. 2004;19(7):1092-8.

41. Lloyd T, Petit MA, Lin HM, Beck TJ. Lifestyle factors and the development of bone mass and bone strength in young women. J Pediatr. 2004;144(6):776-82.

42. Walsh JS, Henry YM, Fatayerji D, Eastell R. Lumbar spine peak bone mass and bone turnover in men and women: a longitudinal study. Osteoporos Int. 2009;20(3):355-62

43. Lu J, Shin Y, Yen MS, Sun SS. Peak bone mass and patterns of change in Total bone mineral density and bone mineral contents from childhood into Young adulthood. J Clin Densitom. 2016;19(2):180-91.

44. Seeman E, Hopper JL, Young NR, Formica C, Goss P, Tsalamandris C. Do genetic factors explain associations between muscle strength, lean mass, and bone density? A twin study. Am J Phys. 1996;270(2 Pt 1):E320-7.

45. Nguyen TV, Howard GM, Kelly PJ, Eisman JA. Bone mass, lean mass, and fat mass: same genes or same environments? Am J Epidemiol. 1998;147(1):3-16 
46. Lang TF. The bone-muscle relationship in men and women. J Osteoporos. 2011:2011:702735.

47. Johansson H, Kanis JA, Odén A, McCloskey E, Chapurlat RD, Christiansen C, et al. A meta-analysis of the Association of Fracture Risk and Body Mass Index in women. J Bone Miner Res. 2013;29(1):223-33.

48. Viljakainen HT, Valta H, Lipsanen-Nyman M, Saukkonen T, Kajantie E, Andersson S, et al. Bone characteristics and their determinants in adolescents and Young adults with early-onset severe obesity. Calcif Tissue Int. 2015;97(4):364-75.

49. Petit MA, Beck TJ, Hughes JM, Lin HM, Bentley C, Lloyd T. Proximal femur mechanical adaptation to weight gain in late adolescence: a six-year longitudinal study. J Bone Miner Res. 2008;23(2):180-8.

50. Sayers A, Tobias JH. Fat mass exerts a greater effect on cortical bone mass in girls than boys. J Clin Endocrinol Metab. 2010;95(2):699-706.

51. Vandewalle S, Taes Y, Van Helvoirt M, Debode P. Herregods N, Ernst C, et al. Bone size and bone strength are increased in obese male adolescents. J Clin Endocrinol Metab. 2013;98(7):3019-28.

52. Dimitri P, Wales JK, Bishop N. Adipokines, bone-derived factors and bone turnover in obese children; evidence for altered fat-bone signalling resulting in reduced bone mass. Bone. 2011:48(2):189-96.

53. Kawai M, De Paula FJ, Rosen CJ. New insights into osteoporosis: the bonefat connection. J Intern Med. 2012;272(4):317-29.

54. Reid IR. Fat and bone. Arch Biochem Biophys. 2010;503(1):20-7.

55. Hamrick MW, Ferrari SL. Leptin and the sympathetic connection of fat to bone. Osteoporos Int. 2008;19(7):905-12.

56. Braun T, Schett G. Pathways for bone loss in inflammatory disease. Curr Osteoporos Rep. 2012;10(2):101-8.

57. Farr JN, Dimitri P. The impact of fat and obesity on bone microarchitecture and strength in children. Calcif Tissue Int. 2017;100(5):500-13.

58. Laddu DR, Farr JN, Laudermilk MJ, Lee VR, Blew RM, Stump C, et al. Longitudinal relationships between whole body and central adiposity on weight-bearing bone geometry, density, and bone strength: a pQCT study in young girls. Arch Osteoporos. 2013;8:156

59. Burrows M, Baxter-Jones A, Mirwald R, Macdonald H, McKay H. Bone mineral accrual across growth in a mixedethnic group of children: are Asian children disadvantaged from an early age? Calcif Tissue Int. 2009; 84(5):366-78.

60. Kim KM, Lim S, Oh TJ, Moon JH, Choi SH, Lim JY, et al. Longitudinal changes in muscle mass and strength, and bone mass in older adults: genderspecific associations between muscle and bone losses. J Gerontol A Biol Sci Med Sci. 2018;73(8):1062-9.

61. Zhu K, Hunter M, James A, Lim EM, Walsh JP. Associations between body mass index, lean and fat body mass and bone mineral density in middleaged Australians: the Busselton healthy ageing study. Bone. 2015;74:146-52.

62. Jiang $Y$, Zhang $Y$, Jin M, Gu Z, Pei Y, Meng P. Aged-related changes in body composition and association between body composition with bone mass density by body mass index in Chinese Han men over 50-year-old. PLoS One. 2015;10(6):e0130400.

63. Lekamwasam S, Weerarathna T, Rodrigo M, Arachchi WK, Munidasa D. Association between bone mineral density, lean mass, and fat mass among healthy middle-aged premenopausal women: a cross-sectional study in southern Sri Lanka. J Bone Miner Metab. 2009;27(1):83-8.

64. Alissa EM, Alnahdi WA, Alama N, Ferns GA. Relationship between nutritional profile, measures of adiposity, and bone mineral density in postmenopausal Saudi women. J Am Coll Nutr. 2014;33(3):206-14.

\section{Publisher's Note}

Springer Nature remains neutral with regard to jurisdictional claims in published maps and institutional affiliations.

Ready to submit your research? Choose BMC and benefit from:
- fast, convenient online submission
- thorough peer review by experienced researchers in your field
- rapid publication on acceptance
- support for research data, including large and complex data types
- gold Open Access which fosters wider collaboration and increased citations
- maximum visibility for your research: over 100M website views per year
At BMC, research is always in progress.
Learn more biomedcentral.com/submissions

